\title{
Angiogenesis Inhibitor GT-111
}

National Cancer Institute

\section{Source}

National Cancer Institute. Angiogenesis Inhibitor GT-111. NCI Thesaurus. Code C71539.

An adenovirus encoding an endothelial cell-specific, murine pre-proendothelin-1 (PPE-1) promoter and a Fas-based chimeric death receptor with potential anti-ang iogenic activity. Endothelial cell-specific transcriptional control of the adenoviral vector is achieved by the use of a modified murine PPE-1 promoter that is specifically activated in PPE-1expressing angiogenic endothelial cells residing in the tumor microvasculature. Subsequently, the Fas-c (Fas-chimeric) death receptor, containing Fas and tumor necrosis factor (TNF) receptor 1 (TNFR1) moieties, is expressed in angiogenic endothelial cells; endothelial cell-specific Fas-mediated apoptosis is initiated by the binding of TNF-alpha, abundant in the tumor microenvironment, to the TNFR1 moiety of the expressed Fas-c death receptor. 